\title{
THE FIRST OCCURRENCE OF THE DEVONIAN RUGOSE CORAL CALCEOLA SANDALINA (LINNÉ, 1771) IN THE BARRANDIAN AREA, CZECH REPUBLIC
}

\section{Michal Mergl}

Center of Biology, Geosciences and Environmental Sciences, Faculty of Education, University of West Bohemia in Plzeň, Klatovská třída 51, 30619 Plzeň, Czech Republic; E-mail: mmergl@cbg.zcu.cz

\begin{abstract}
The calceolide coral Calceola sandalina (Linné, 1771) has been observed in the Acanthopyge Limestone (Choteč Formation, Eifelian) in the Koněprusy area, Czech Republic. Its presence in the Barrandian area indicates absence of significant palaeogeographic barriers restricting the distribution of this tetracoral in the Middle Devonian. Association of Calceola with a taxonomically diverse ribbed brachiopod faunas attests for two different types of environment on the Koněprusy submarine elevation during deposition of the Acanthopyge Limestone. Calceola-bearing beds represent a high-energy reefal environment different from somewhat deeper and calmer environment characterized by smooth-shelled, small to medium sized spire-bearing brachiopods.
\end{abstract}

Key words: Calceola, Calceolitidae, Eifelian, Koněprusy reef, Barrandian, Czech Republic

\section{INTRODUCTION}

The distinctive rugose coral Calceola Lamarck, 1799 is an easily recognizable Devonian fossil. Its worldwide distribution includes France, Germany, Belgium, Poland, Moravia, North Africa, southern
China and eastern Australia. As noted by Wright et al. 2010, that genus was largely a Gondwanan fauna element. Calceola sandalina (Linné, 1771) is widespread during the Emsian, Eifelian, and
Bohemian Massif and Devonian rocks of the Prague Basin

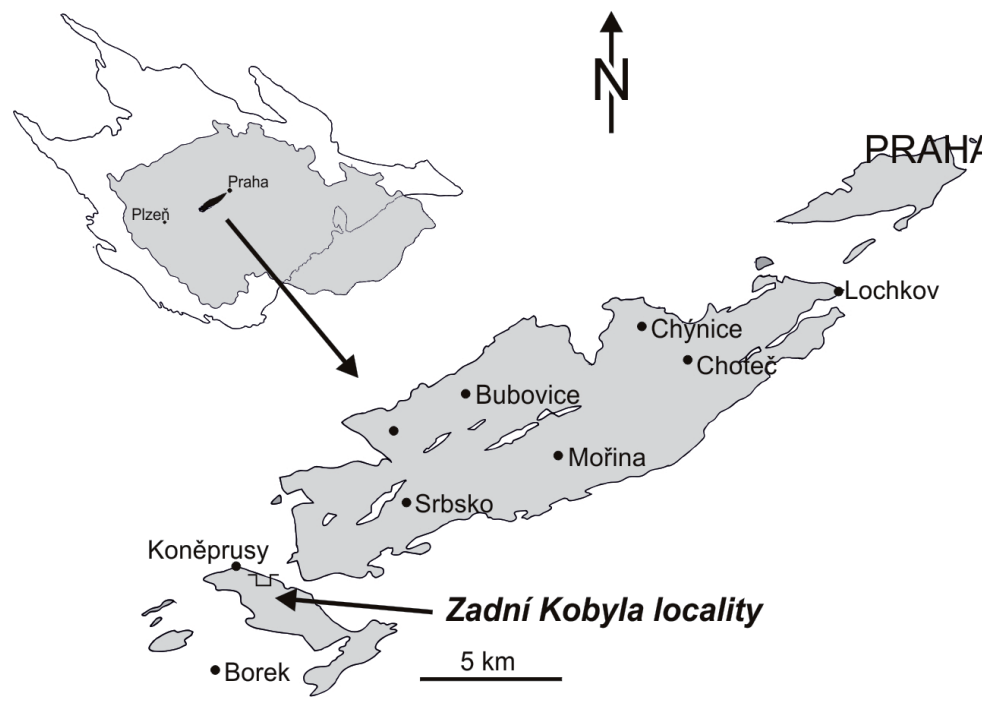

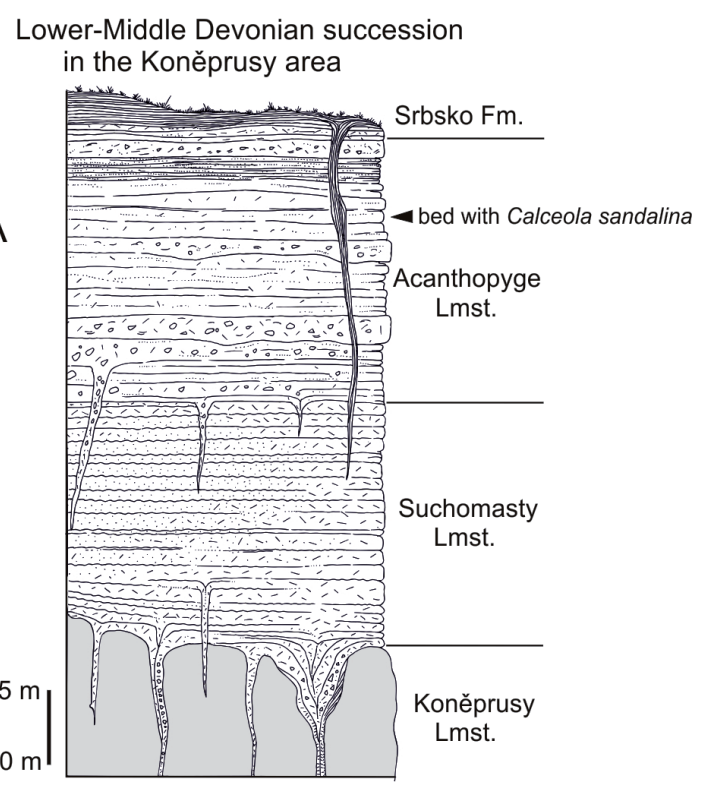

Figure 1. Sketch map of the Devonian of the Prague Basin, and generalised stratigraphy of the Koněprusy Limestone (Pragian), Suchomasty Limestone (Upper Emsian), Acanthopyge Limestone (Eifelian), and the top of the Acanthopyge Limestone and the Srbsko Formation (transition Eifelian-Givetian) in the Koněprusy area with marked neptunian dykes and approximate positions of Calceola-bearing limestone bed. Modified after Chlupáč et al. (1986) and Hladil et al. (1992). 


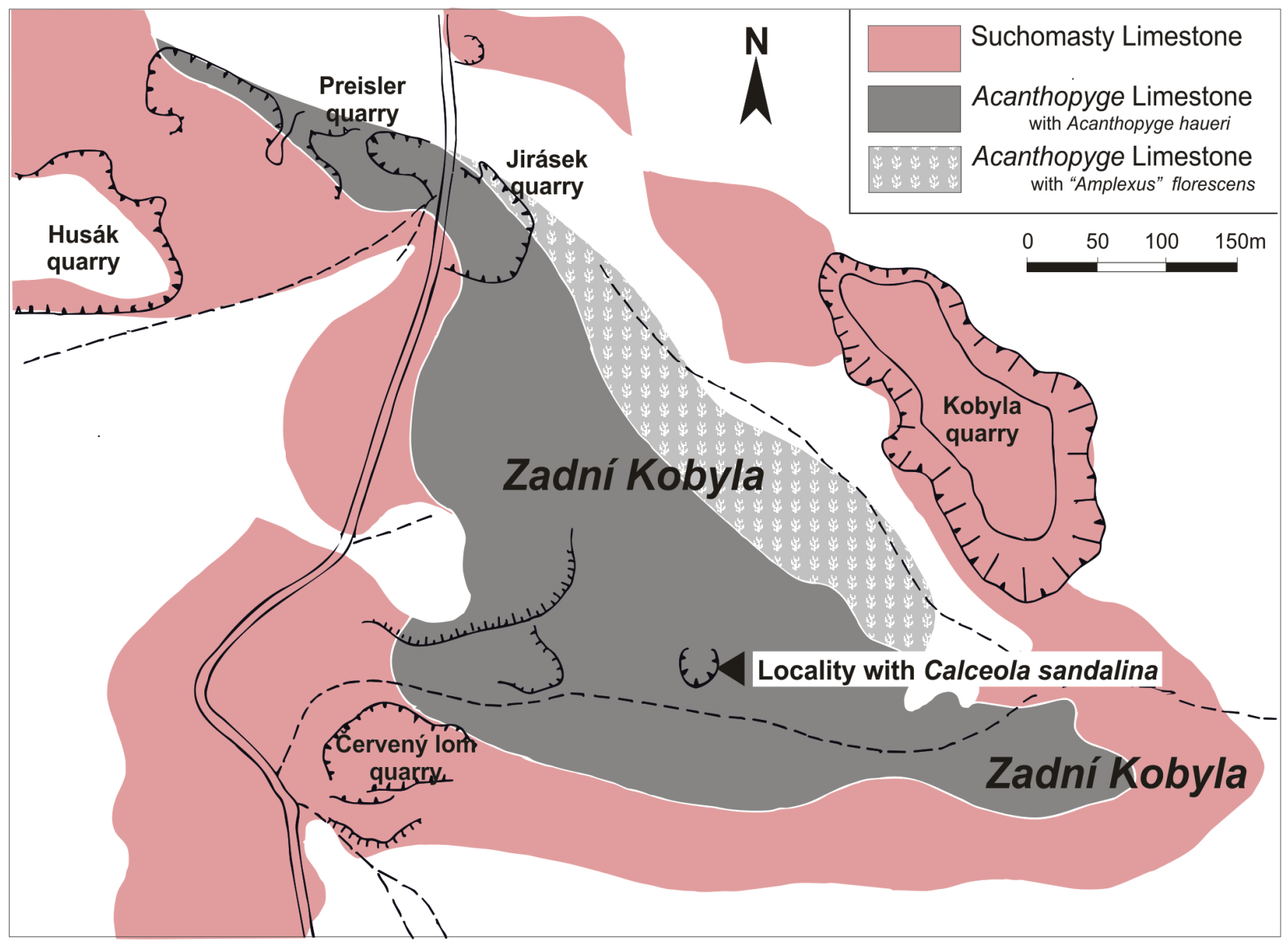

Figure 2. General geological map of the Emsian (Suchomasty Limestone) and Eifelian (Acanthopyge Limestone) rocks at Zadni Kobyla ridge with marked Calceola-bearing locality. Modified after Svoboda \& Prantl (1949).

Givetian outside the Barrandian area. The nearest present occurrence of Calceola sandalina outside of the Barrandian found in the late Eifelian and Givetian of Moravia (Richter, 1928; Špinar, 1951; Strnad, 1960; Galle, 1995; Galle \& Ficner, 2004; Galle \& Mikuláš, 2003) and the Givetian of Poland (Pajchlowa, 1957; Stolarski, 1993; Malec, 2005; Malec \& Turnau, 1997). Modern revision and comments to new occurrences were given by Wright (2010) and Wright et al. (2010).

Although Calceola is a widely distributed taxon it has never been found in the sediments of the late Emsian, Eifelian or early Givetian age in the Barrandian (Prague Basin) despite the intensive sampling of fossils in this area for more than 150 years. Prantl (1937) referred two poorly preserved specimens from the locally developed perireefal limestone accumulations of the early Emsian age (Zlíchovian) (locality Praha-Hlubočepy, Kaplička coral horizon) to Calceola sandalina (Linné, 1771). These two specimens were subsequently revised by Oliver \& Galle (1971) and re-assigned to Rhizophyllum sp. Other calceolide species of Rhizophyllum Lindström, 1866 has been revised by Galle (1971). This unique corallite was previously described as Rhizophyllum bohemicum already by Počta (1902). This specimen was probably collected from the Koněprusy Limestone of Pragian age.

New material of the calceolide tetracoral has been obtained from the Acanthopyge Limestone (Eifelian) at Zadní Kobyla ridge of the Koněprusy area (Figs 1-3). Its morphology, stratigraphical level, ecological and palaeogeographical significance are discussed herein. 


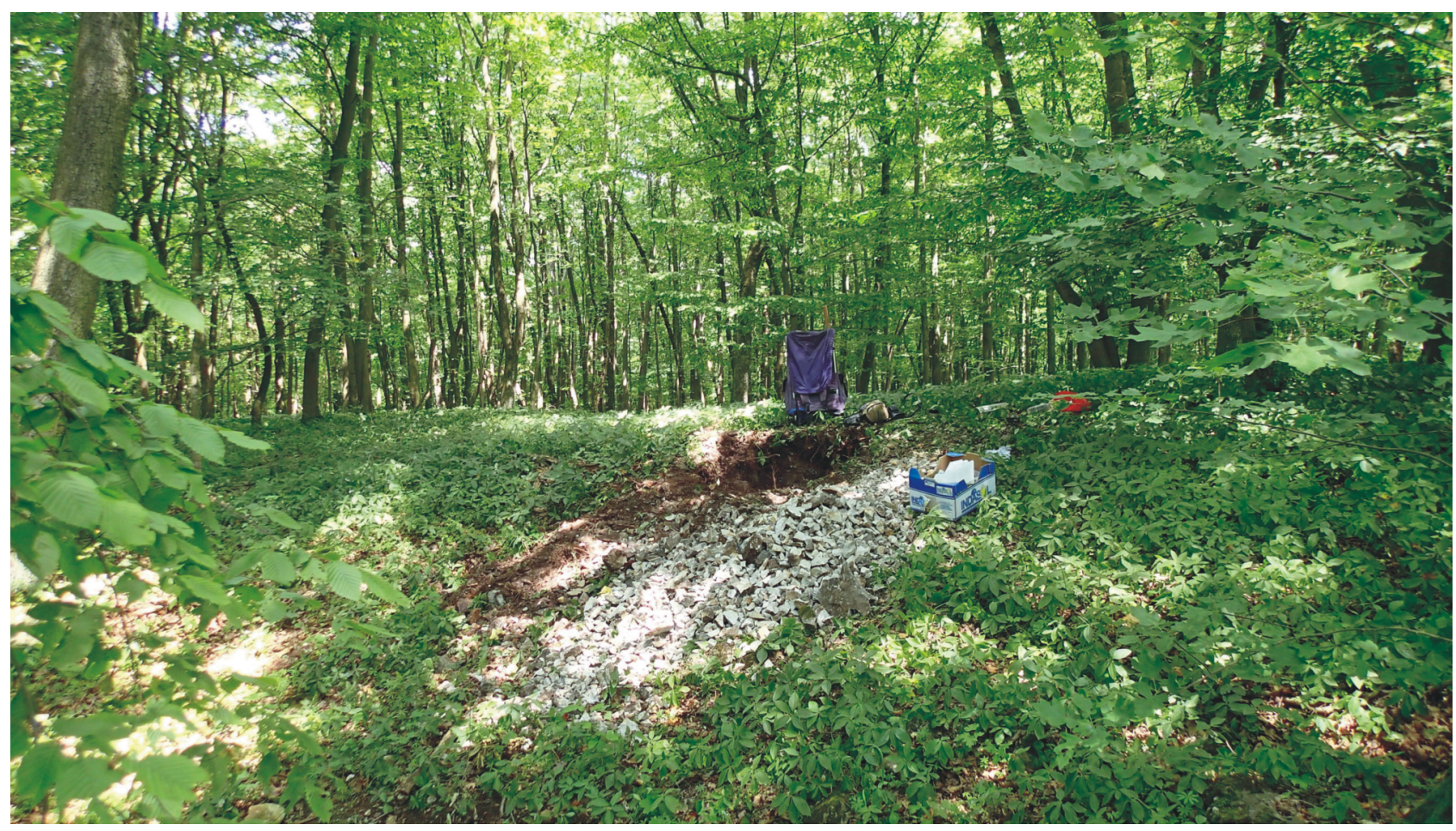

Figure 3. View on the Zadní Kobyla locality in the Koněprusy area.

\section{METHODS}

All specimens were sampled by hammering from the massive white crinoidal limestone. None serial sections were made, because inner corallite morphology is clearly distinct in two natural internal moulds. All figured specimens are stored in the collections of the Center of Biology, Earth and Environmental Sciences of the University of West Bohemia at Plzeň (PCZCU 1978 to PCZCU1986, and PCZCU 1988). Terminology and orientation follows Wright (2010) and Wright et al. (2010) with terms: OEF - opercular external face, OIF opercular internal face, KEF - counter external face, KIF - counter internal face, and KOF - posterior external face of operculum.

\section{MATERIAL AND PRESERVATION}

In total, ten specimens of Calceola were collected from the $30 \mathrm{~cm}$ thick limestone bed. Three opercula (PCZCU 1978-1980) and seven corallites (PCZCU 1981-1986, 1988) have been sampled. All specimens are disarticulated. Except one specimen (PCZCU 1978), all other specimens have preserved slightly recrystallized sclerenchyma. Calices of all corallite are filled by limestone. One corallite (PCZCU 1982) has secondarily weathered surface showing the septa. One operculum (PCZCU 1979) exhibits abrasion. Another operculum (PCZCU 1978) is preserved as internal and external moulds. Two natural internal moulds of corallite (PCZCU 1986 and 1988) display a septal structure on the KIF. These different modes of preservation sufficiently illustrate all diagnostic features of corallites referred to Calceola.

\section{Geographical and geological setting of the Barrandian material}

The Acanthopyge Limestone is local member of the Choteč Formation, representing shallow marine deposits of the peri-reef environment at the top the Koněprusy submarine elevation. The member is built of generally well washed grainstone/ rudstone, crinoidal limestone and bahamites (Havlíček \& Kukal, 1990; Galle et al., 1991). The topmost sequence of the dark bedded limestone has been correlated with the Kačák Member and the Kačák event (Hladil et al., 1992; Hladil, 1993). Eifelian age of the Acanthopyge Limestone is sufficiently proved by goniatites (Chlupáč \& Turek, 
1983), conodonts (Zikmundová \& Kalvoda in Galle et al., 1991; Berkyová, 2009) and other invertebrates. The Eifelian/Givetian transitional interval above the dark interval of the Acanthopyge Limestone is evidenced by index tabulatomorphs and stromatoporoids (Hladil, 1993).

All specimens are from the upper part of the Acanthopyge Limestone outcropping in a small shallow abandoned quarry in Zadní Kobyla ridge near Koněprusy, Central Bohemia (Figs 1, 2A). Fossiliferous limestone rich in brachiopods, crinoids and corals including Calceola form small outcrops along the low NE slope of the quarry (Fig. 3B).

Corallites and opercula of Calceola sandalina have only been observed in the crinoidal white limestone bed incorporated in a several metre thick succession of white limestone at the upper onethird of the Acanthopyge Limestone (limestone with "Amplexus" florescens by Svoboda \& Prantl, 1949). Richly fossiliferous white crinoidal limestone beds outcrop above about a $2 \mathrm{~m}$ thick bed of light to dark grey spongolitic limestone (Svoboda $\&$ Prantl, 1949). Conodonts are very rare, but the presence of Tortodus kockelianus indicates the Tortodus kockelianus Zone of the upper Eifelian.

\section{SYSTEMATICS}

\section{Family CALCEOLIDAE King, 1846}

Calceola Lamarck, 1799

Type species: Anomia sandalium Linné in Gmelin, 1790 (= A. sandalinum Linné, 1771).

Calceola sandalina (Linné, 1771) (Plates I, II) Description: Corallite is typically slipper-shaped, with apical angle about $30^{\circ}$ in early growth stages increasing to $60^{\circ}$ in maturity in the largest known specimen. Walls of corallite are about $2 \mathrm{~mm}$ thick at $10 \mathrm{~mm}$ distance from the base of corallite. Maximum length of corallite is $28 \mathrm{~mm}$. KEF is gently to moderately curved, showing growth lines, but lacking a distinct median ridge. Septal traces are seen on the KEF as fine grooves. Operculum is thick-walled, with much thickened posterior part, semiovate in outline, with prominent growth bands which are semicircular in early growth stages. KOF of operculum corresponds to the KEF of the corallite. OEF is gently convex but some- what irregular in one specimen (PCZCU 1979). OIF is gently concave in general, with thickened posterior having gently convex surface. Eight septal blades developed on each side, with much lateral ones gently diverging each another.

Median septum is low, bifurcating posteriorly and forming the pit for articulation for the distal of the median septum of the corallite. There is a row of low rounded knobs immediately inside the posterior edge of the operculum. Eleven shallow pits are aligned along the posterior edge of corallite. 11 to 12 major septa are on each side of KIF. $\mathrm{K}$-septum is clearly developed. Major septa are $0.5 \mathrm{~mm}$ apart, inserted minor septa are weaker than major septa. All septa are weakly curved. Rows of desmocyte attachment scars inserted between septa are clearly discernible on KIF.

Exterior of the largest corallite bears a few growth bands covered by much finer but distinct growth lines numbering 6 to 10 per $1 \mathrm{~mm}$.

Remarks: The specimens, despite less favourable preservation, are morphologically undistinguishable from specimens of C. sandalina (Linné, 1771) from Moravia, Germany, Belgium and France. There is an extensive literature about the distribution of C. sandalina in West Europe (for a review see Wright et al., 2010). Identification of sampled corals to species is based on the internal morphology of the operculum. Morphology of the single preserved operculum shows OIF features (Plate I, Figs 1,4) attributed to Calceola. Number, size and arrangement of septal blades and K-septum of other calceolide genera (Chakeola Wright 2001, Richtereola Wright, 2006, Rhizophyllum Lindström, 1866, and Savageola Wright, 2001) differ from those of herein described Bohemian calceolide. Calceola represent the final genus of the generic evolutionary sequence of Rhizophyllum $\rightarrow$ Savageola $\rightarrow$ Chakeola $\rightarrow$ Richtereola $\rightarrow$ Calceola (Wright, 2010). The supposed upper Eifelian age of the Calceola-bearing bed in the Koněprusy area indirectly supports attribution of specimens to Calceola sandalina.

Occurrence in Bohemia: Eifelian, Choteč Formation, Acanthopyge Limestone (upper part with "Amplexus" florescens); Barrandian area, a small abandoned quarry on Zadní Kobyla ridge near Koněprusy. 

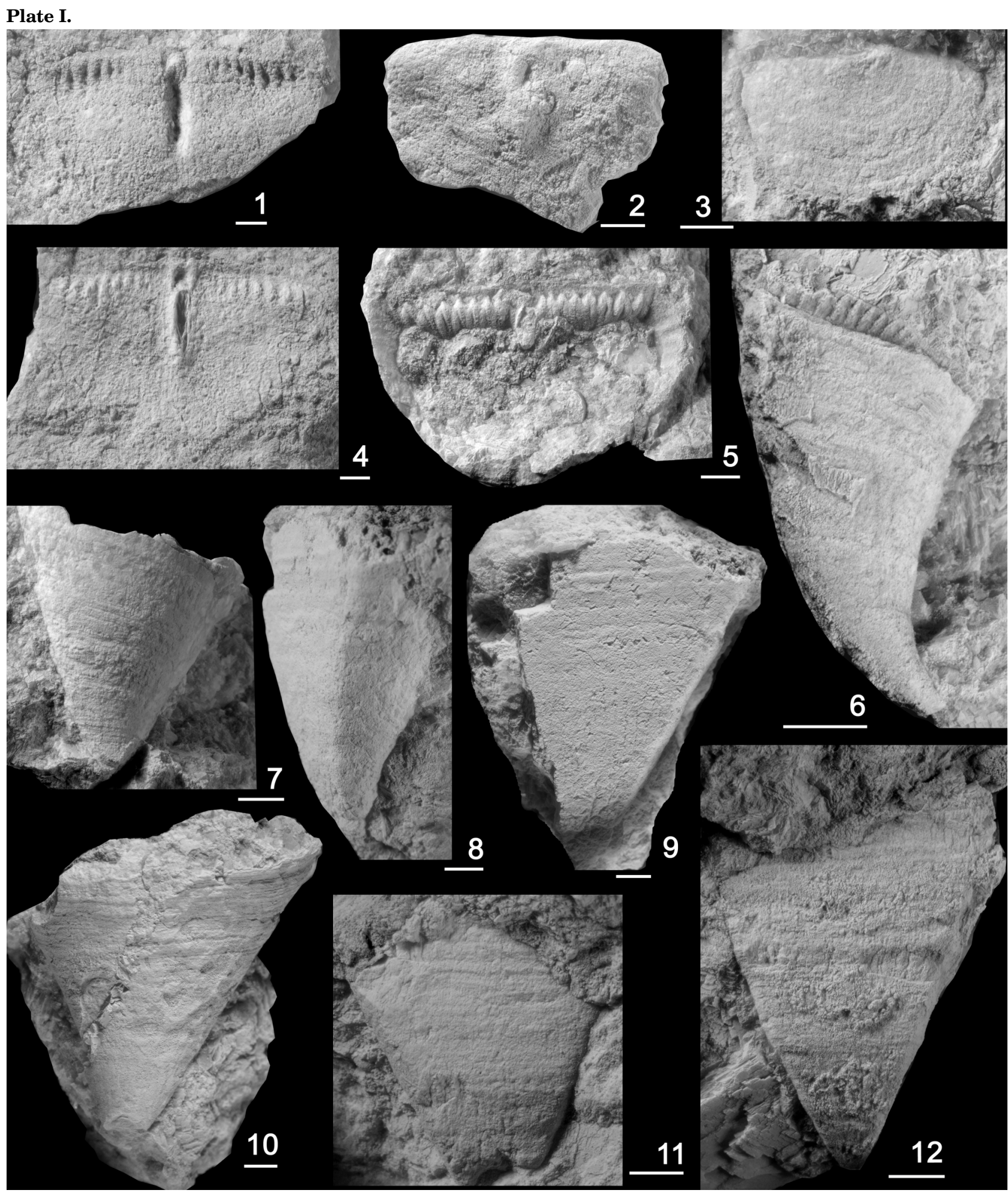

Plate I. Calceola sandalina (Linné, 1771). Eifelian, Acanthopyge Limestone, Zadní Kobyla locality, Koněprusy area, Central Bohemia; Scale bar $2 \mathrm{~mm}$; 1) and 4) operculum, internal mould and its inner surface (OIF) of PCZCU 1978; 2) inner surface (OIF) of abraded operculum, PCZCU 1979; 3) small operculum, PCZCU 1980; 5) and 7) calical and lateral views to corallite, PCZCU 1981; 6) and 12) side view to corallite and its counter side (KOF), PCZCU 1982; 8) and 9) laterocardinal view to corallite and KOF of the same corallite, PCZCU 1983; 10) cardinal view to corallite, PCZCU 1984; 11) growth lines on KOF of the smallest known corallite, PCZCU 1985. 


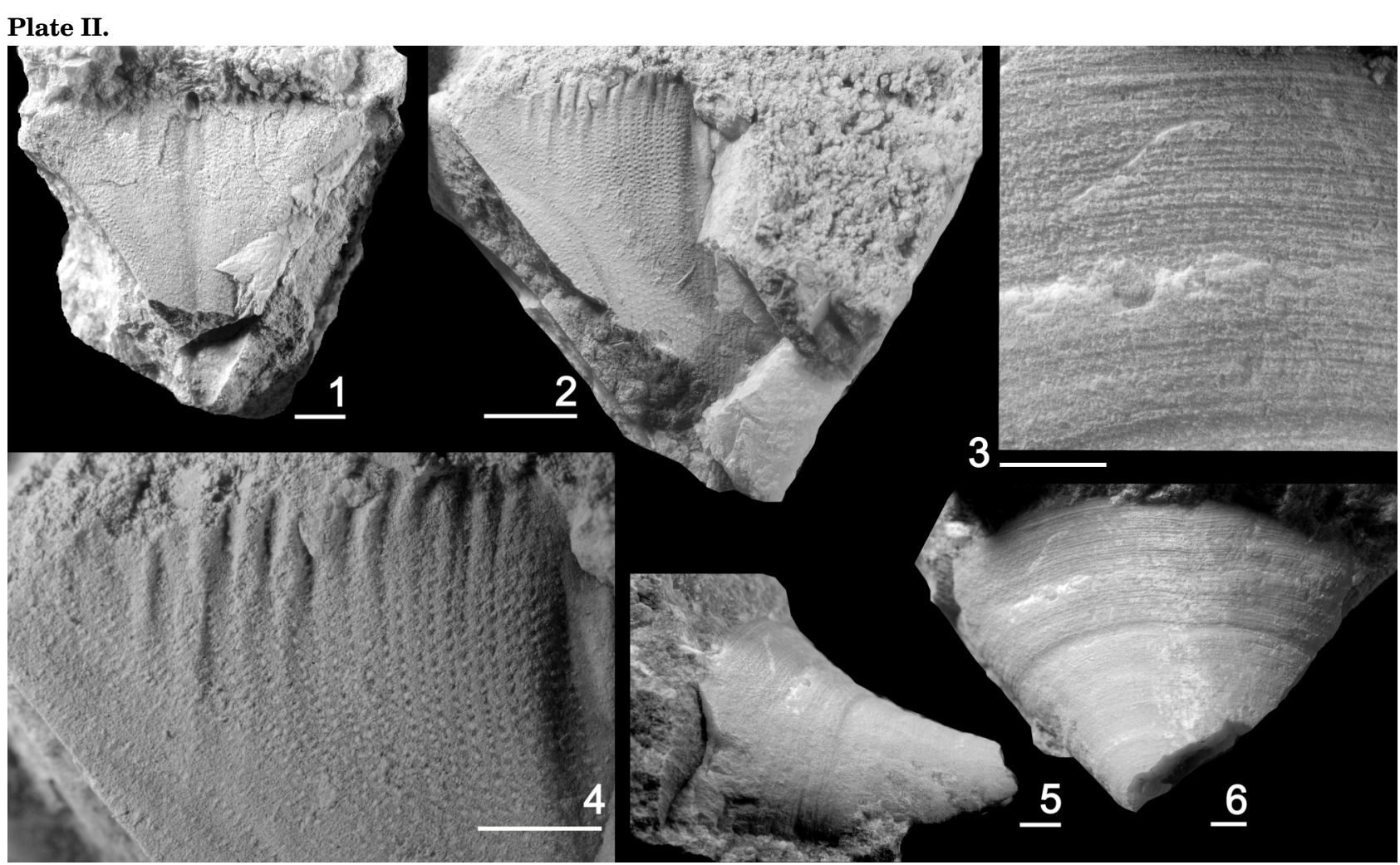

Plate II. Calceola sandalina (Linné, 1771). Eifelian, Acanthopyge Limestone, Zadní Kobyla locality, Koněprusy area, Central Bohemia. Scale bar $2 \mathrm{~mm}$; 1) internal mould of KIF showing K-septum, septa, and desmocyte scars, PCZCU 1986; 2) - 6) corallite with partly broken wall showing major septa, minor septa, and part of K-septum on KIF natural internal mould (2), detail of KIF showing rows of desmocyte scars between septa and insertion of minor septa (4), lateral and cardinal views to corallite $(5,6)$, and detail of growth lines on surface of the corallite (3), PCZCU 1988.

\section{DISCUSSION}

\section{Palaeoecology}

In the Acanthopyge Limestone, Calceola sandalina (Linné, 1771) is commonly associated with crinoids (represented by columnalia and pluricolumnaria), rhynchonelliform brachiopods, stromatoporoids, tabulate, heliolitid and rugose corals, and other rare invertebrates (phacopid, proetid, lichid and scutelluid trilobites, platyceratid gastropods, small bivalves, fenestrate and trepostomate bryozoans, benthic tentaculitids). The absence of other gastropods, cephalopods, crustaceans, organophosphatic brachiopods and conulariids is noteworthy. Conodonts (under study) are very rare with Belodella, Polygnathus, and Tortodus (S. Vodrážková, pers. com.) so far having been identified.

A notably high diversity of rhynchonelliform brachiopods occur with Calceola sandalina. The rhynchonelliform genera and species found here are extremely rare or previously unknown from other fossiliferous localities of the Acanthopyge Limestone. Costate or ribbed brachiopods are much more common in the Calceola-bearing bed at Zadní Kobyla than among the brachiopod faunas in this limestone immediately below and above in which the smooth-shelled forms are most common. The remarkable brachiopod diversity and high morphological disparity of orthids (Aulacella, Isorthis, Schizophoria), large strophomenoids (Chonostrophia, Leptaena, Leptaenopyxis, chonetoids (Devonaria), rhynchonellids (Kransia), pentameriods (Ivdelinia, Sieberella), athyrids (Merista), spiriferids (Amoenospirifer, Cyrtina, Myriospirifer), costate atrypids (Anatrypa, Atryparia, Carinatina, Desatrypa, Planatrypa, Spinatrypa, Variatrypa) and other brachiopod groups (Iridistrophia, Denovalosia) indicate reef environment. High-energy environment is evidenced by the large fragments of thick-walled shells, abraded and rolled corals and stromatoporoids, and finely fragmented fenestrate bryozoans. This distinguishes 
the fossils of the Calceola-bearing limestone bed from limestone beds above and below, which are interpreted as having been deposited under significantly lower energy regimes as these fossils are less fragmented. The small to medium sized smooth-shelled spire-bearing brachiopods and arborescent corals are dominant there. This striking environmental difference may explain the absence of the $C$. sandalina from other limestone beds of the Acanthopyge Limestone. This confirms unique nature of the Calceola-bearing beds within the Acanthopyge Limestone succession. The mode of preservation and the taxonomic similarity between the older Koněprusy Limestone (Pragian age) and younger Acanthopyge Limestone (Eifelian age) biota indicate a restoration of a similar reefal environment for a short episode in the Upper Eifelian.

\section{Paleobiogeography}

Based largely on the differences of the brachiopod fauna in conjunction with the abundance of $C$. sandalina in the latest Emsian, Eifelian and the Givetian of Germany, Belgium, France, Poland and Moravia, and C. sandalina's heretofore absence in the Eifelian to Givetian of Central Bohemia supported the suggested palaeogeographic separation of the Barrandian marine space from that of West European, at least in the Middle Devonian (Havlíček, 1994). Immigration of Rhenish-type brachiopods into reef environment of the Barrandian in the lowest Emsian was a subject of special paper (Havlíček, 1994). He proposed that the immigration was only short-lasted and restricted to a few species. After this episode, the reestablishmentof the barrier between the Rhenish region and Central Bohemia restored. Havlíček \& Kukal (1990) stated taxonomic similarity of the smooth-shelled, spire-bearing brachiopods of the Karbous-Orbitoproetus Community of the Eifelian age in the Barrandian with the brachiopod and trilobite fauna of the Greifenstein Limestone in Rheinishes Schiefergebirge, Germany (Siehl, 1962), but without any palaeogeographic comments and conclusions.

Presence of $C$. sandalina associated with many reef biota as seen also in the Rhenish region indicates lack of barrier for interchange of benthic biotas, at least during the Eifelian. The faunal differences reflect environmental differences rather than the presence of palaeogeographic barriers.

\section{CONCLUSIONS}

The calceolide coral collected in the Acanthopyge Limestone (Eifelian) in the Koněprusy area is without doubts identified as Calceola sandalina (Linné, 1771). The species is widespread in many late Emsian, Eifelian and Givetian sites of West Europe, Poland and Moravia. Its presence in the Barrandian area indicates absence of significant palaeogeographic barriers restricting distribution of this coral in the Middle Devonian. Presence of Calceola and associated diverse and highlydisparate brachiopod faunas attest for two different types of environmental setting on the Koněprusy submarine elevation during a deposition of the Acanthopyge Limestone. The Calceola-bearing beds represent a high-energy reef environment. Somewhat deeper calmer environment is characterized by spire-bearing, smooth-shelled, small to medium sized brachiopods of the Karbous-Orbitoproetus Community in the sense of Havlíček \& Kukal (1990).

\section{ACKNOWLEDGEMENTS}

Author is greatly indebted to Stanislava Vodrážková for determination of the conodonts. This study was supported by a grant of the Grant Agency of the Czech Republic GAČR No. P210-12-2018.

\section{REFERENCES}

Berkyová, S. 2009. Lower-Middle Devonian (upper Emsian-Eifelian, serotinus-kockelianus zones) conodont faunas from the Prague Basin, the Czech Republic. Bulletin of Geosciences 84(4), 667-686.

Chlupáč, I., Hladil, J. \& Lukeš, P. 1986. Barrandian - Moravian Karst 1986. Excursion - Guidebook. Subcomission on Devonian Stratigraphy of the International Commission on Stratigraphy. 62 pp. Ústřední ústav geologický, Praha.

Chlupáč, I., \& Turek, V. 1983. Devonian goniatites from the Barrandian area, Czechoslovakia. Rozpravy Ústředního ústavu geologického 46, $1-159$.

Galle, A. 1971. Rugose corals from the Upper Koněprusy Limestone (Lower Devonian) in Bohemia. Sborník geologických věd, Paleontologie 16, 35-106. 
Galle, A. 1995. The Breviphrentis-dominated coral faunule from the Middle Devonian of Moravia, Czech Republic. Věstník Českého geologického ústavu 70(2), 59-70.

Galle, A. \& Ficner, F. 2004. Middle Devonian Calceola sandalina (Linnaeus, 1771) (Anthozoa, Rugosa) from Moravia (Czech Republic): aspects of functional morphology, gerontic growth patterns, and epibionts. Geodiversitas 21(1), 17-31.

Galle, A. \& Mikuláš, R. 2003. Evidence of predation on the rugose coral Calceola sandalina (Devonian, Czech Republic). Ichnos 10, 41-45.

Havlíček, V. 1994. Immigration of the Rhenishtype and Australian brachiopod stocks into the Prague Basin (Central Bohemia) in the lowest Emsian (Lower Devonian). Věstník Českého geologického ústavu 69(4), 41-46.

Havlíček, V. \& Kukal, Z. 1990. Sedimentology, benthic communities, and brachiopods in the Suchomasty (Dalejan) and Acanthopyge (Eifelian) Limestones of the Koněprusy area (Czechoslovakia). Sborník geologických věd, Paleontologie 31, 105-205.

Hladil, J. 1993. Tabulatomorphs and stromatoporoids below and above the upper boundary of the Acanthopyge Limestone (Eifelian/Givetian transition interval, Central Bohemia). Věstník Českého geologického ústavu 68(2), 27-42.

Hladil, J., Beroušek, P. \& Lukeš, P. 1992. Temné vápencové vrstvy při stropu akantopygových vápenců u Koněprus - otomari-Kačák event. Zprávy o geologických výzkumech v roce 1991, 53-55.

King, W. 1846. Remarks on certain genera belonging to the Palliobranchiata. Annals and Magazine of Natural History, series 1, 18, 26-42, 8394.

Lamarck, J.B.P.A. De M. 1799. Prodrôme d'une nouvelle classification des coquilles, comprenant une rédaction appropriée des caractères génériques, et l'établissement d'un grand nombre de genres nouveaux. Mémoires de la Société d'Histoire Naturelle de Paris 1, 63-91.

Lindström, G. 1866. Några iakttagelser öfver Zoantharia rugosa. Öfversigt af Kungliga SvenskaVetenskaps Akademiens Förhandlingar 22, 271-294.

Linné, C. 1771. Mantissa plantarum altera generum editionis VI \& specierum editionis II. Laurentii Salvii, 143-588, Stockholm.
Linné, C. 1790. 3021-3909. In Gmelin, J.F. (ed.), Systema naturae per regna tria naturae, secundum classes, ordines, genera, species, cum characteribus, differentiis, synonymis, locis. Tomus 1, pars VI, G.E. Beer, Leipzig.

Malec, J. 2005. Lithostratigraphy of the Lower and Middle Devonian boundary interval in the Lysogory Region of the Holy Cross Mts (Poland). Biuletyn Panstwowego Instytutu Geologicznego 415, 5-58.

Malec, J. \& Turnau, E. 1997. Middle Devonian conodont, ostracod and miospore stratigraphy of the Grzegorzowice-Skaly Section, Holy Cross Mountains, Poland. Bulletin of the Polish Academy of Sciences, Earth Sciences 45, 67-86.

Oliver, W. A. \& Galle, A. 1971. "Calceola" (= Rhizophyllum) and "Billingsastraea" (=Iowaphyllum) in Bohemia. Věstník Ústředního ústavu geologického 46, 209-216.

Počta, P. 1902. Prague. Anthozoaires et Alcyonaires. In Barrande, J. Systéme Silurien du centre de la Boheme, Tome 8, 2, 1-347.

Prantl, F. 1937. Erster Fund der Calceola sandalina (L.) im Böhmischen Devon. Zentralblatt für Mineralogie B2, 109-111.

Pajchlowa, M. 1957. The Devonian in the Grzegorzowice-Skaly profile (Swiety Krzyz Mts). Biuletyn Instytutu Geologicznego 122, 145-254.

Richter, R., 1928. Fortschritte in der Kenntnis der Calceola-Mutationen. Senckenbergiana 10, 169184.

Siehl, A. 1962. Der Greifensteiner Kalk (Eiflium, Rheinisches Schiefergebirge) und seine Brachiopodenfauna. Palaeontographica, Abteilung A 119, 173-221.

Stolarski, J. 1993. Ontogenetic changes and functional morphology in the early growth-stages of Calceola sandalina (Linnaeus, 1771). Courier Forschungsinstitut Senckenberg 164, 169-177.

Strnad, V. 1960. Calceola sandalina in the Devonian near Horní Benešov. Př́rodovědecký Časopis slezský 21(1), 123-124.

Svoboda, J. \& Prantl, F. 1949. Stratigraficko-tektonická studie o devonské oblasti koněpruské. Sborník Státního geologického ústavu Ceskoskovenské republiky 16, 5-92.

Špinar, Z. 1951. Nález druhu Calceola sandalina (Linné, 1771) a nové naleziště stromatoporoideí u Vratíkova na Moravě. Věstník Ústředního ústavu geologického 16, 133-134. 
Wright, A.J. 2001. A new Early Devonian operculate coral genus from eastern Australia. Records of the Western Australian Museum, Supplement 58, 21-35.

Wright, A.J. 2006. New genera of Early Devonian calceolide corals from Australia and France. Palaeoworld 15, 185-193.

Wright, A.J. 2010. Septal architecture and palaeoecology of Calceola (Cnidaria, Calceolidae), with comments on the phylogeny of Devonian operculate tetracorals. Memoirs of the Association of Australasian Palaeontologists 39, 159-176.

Wright, A.J., Coen-Aubert, M., Bultynck, P. \& van Viersen, A.P. 2010. New data on occurrences of the Devonian rugose coral Calceola in Belgium. Memoirs of the Association of Australasian Palaeontologists 39, 121-129.

Zikmundová, J. \& Kalvoda, J. 1991. Provisional list of conodonts. In Galle, A. \& Hladil, J. (eds) Lower Paleozoic corals of Bohemia and Moravia. VI. International Symposium of Fossil Cnidaria including Archaeocyatha and Porifera, Münster, Germany, Excursion Guidebook B3, 24-25.Westfälischen Wilhelms Universität Münster, Münster. 